\title{
Practical commentary on therapeutic guidelines for isolated nail lichen planus 2020
}

\author{
Uwagi praktyczne do wytycznych z 2020 roku dotyczących terapii izolowanego \\ liszaja płaskiego narządu paznokciowego
}

\author{
Andrzej K. Jaworek', Przemysław Hałubiec², Judyta Maciejowska-Podosek', Anna Wojas-Pelc' \\ 'Department of Dermatology, Jagiellonian University Medical College, Krakow, Poland \\ ${ }^{2}$ The Student Dermatology Science Club, Jagiellonian University Medical College, Krakow, Poland \\ 'Katedra i Klinika Dermatologii, Uniwersytet Jagielloński Collegium Medicum, Kraków, Polska \\ ${ }^{2}$ Studenckie Koło Naukowe Dermatologii, Uniwersytet Jagielloński Collegium Medicum, Kraków, Polska \\ Dermatol Rev/Przegl Dermatol 2021, 108, 77-80 \\ DOI: https://doi.org/l0.5। |4/dr.2021. 105899
}

Lichen planus (LP) is a chronic, inflammatory dermatosis characterized by presence of polygonal, flat-raised, purple-red papules and intense itching [1]. Incidence of the disease is estimated at $0.1-1.0 \%$. Apart from the skin, the disease may also affect mucosa, hair and nails ( $10 \%$ of LP cases). More than 20 clinical and morphological variants of LP have been identified, closely related to location of lesions. Location of lesions is an important diagnostic clue the most commonly there are symmetrical lesions on wrists, forearms or ankles. The Koebner's symptom and the presence of Wickham striae on the lesion surface are helpful in clinical diagnostics. Dermoscopic criteria (Wickham striae, matt red background, peripheral arrangement of blood vessels) are increasingly common. In ambiguous cases, a biopsy of lesions with subsequent histopathological assessment is recommended. Etiology of LP has not been clearly established yet. Among numerous hypotheses, the most common assumption is that an undefined factor induces an autoimmune response of $\mathrm{CD} 8+$ and CD45Ro+ T cells directed to basal epidermal keratinocytes, leading to their apoptosis [1,2].

Especially in cases of isolated involvement of nails (nail lichen planus - NLP), the diagnosis and therapy of LP remains a challenge [1].

Clinical symptoms of NLP depend on location of lesions [3-5]. Usually, many nails are inflamed, although thumbs are most typically affected. In toenail area, changes are usually asymptomatic (thickening of the nail plates). Bullous and erosive LP forms in the area of nails are particularly dramatic and unfavorable. They usually affect feet and are extremely painful. Untreated they lead to permanent loss of nail
Liszaj płaski (lichen planus - LP) jest przewlekłą dermatozą zapalną, która cechuje się obecnością wielobocznych, płasko-wyniosłych, fioletowo-czerwonych grudek oraz intensywnego świądu [1]. Szacuje się, że liczba zachorowań wynosi 0,1-1,0\%. Poza skórą choroba może dotyczyć również błon śluzowych, włosów i aparatu paznokciowego ( 10\% przypadków LP). Wyszczególniono ponad 20 odmian kliniczno-morfologicznych LP, powiązanych ściśle z umiejscowieniem zmian. Lokalizacja wykwitów stanowi istotną wskazówkę diagnostyczną - najczęściej stwierdza się symetryczne zmiany na nadgarstkach, przedramionach lub $\mathrm{w}$ okolicy stawów skokowych. W diagnostyce klinicznej pomocne są objaw Koebnera oraz obecność siateczki Wickhama na powierzchni zmian. Coraz powszechnej stosowane są kryteria dermoskopowe (siateczka Wickhama, matowoczerwone tło, obwodowy układ naczyń krwionośnych). $\mathrm{W}$ przypadkach niejednoznacznych zaleca się biopsję zmian z oceną histopatologiczną. Etiologia LP nie została dotychczas jednoznacznie poznana. Wśród licznych hipotez najpowszechniej przyjmuje się, że nieokreślony czynnik wywołuje reakcję autoimmunologiczną limfocytów T CD8+ oraz CD45Ro+ w stosunku do keratynocytów warstwy podstawnej naskórka, co prowadzi do ich apoptozy $[1,2]$.

Diagnostyka i terapia LP stanowią wyzwanie zwłaszcza w przypadkach izolowanego zajęcia przez proces zapalny aparatu paznokciowego (nail lichen planus - NLP) [1].

Kliniczne objawy NLP zależą od lokalizacji zmian [3-5]. Zazwyczaj procesem zapalnym objęte są liczne paznokcie, chociaż najbardziej typowe są zmiany na kciukach. W obrębie aparatu paznokciowego stóp zmiany są zwykle asymptomatyczne (pogrubienie płytek pa- 
plates (anonychia). Also, idiopathic atrophy of nails, characterized by a sudden, painless course, is nowadays treated as a rare, particularly severe variant of LP, that occurs in Asians and African Americans.

Differential diagnosis of NLP is difficult and is based on an early and properly performed (depending on the clinical presentation of changes) biopsy. Diseases that require differentiation from NLP include: lesions related to the aging process of nails, changes in nails caused by radiotherapy, onychomycosis, psoriasis, Stevens-Johnson syndrome, yellow nail syndrome, systemic amyloidosis, eczema lesions and band lichen. In the canonical textbook of onychology by Baran and Dawber, attention is drawn to the possible development of non-pigmented nail melanoma, resembling symptoms of NLP [3].

Treatment of NLP remains a challenge for physicians, and the contemporary literature emphasizes the need for true nail emergency [6]. In 2020, a group of international experts published in the Journal of the American Academy of Dermatology the first set of recommendations for NLP therapy [7]. Authors classified severity of lesions, emphasizing that both the dorsal pterygium and the anonychia were the most severe and non-responding to therapy forms of the disease. Based on our own experience and the review of literature (21 publications from the PubMed database), a practical therapeutic algorithm was developed, providing the division based on: the number of involved nails ("up to 3" and "more than 3"), involvement of the nail matrix and/or nail bed.

Authors recommend local injections of triamcinolone acetonide $\left(1^{\text {st }}\right.$-line therapy; concentration of 2.5-5.0-10.0 mg/ ml, depending on severity of lesions; $0.1 \mathrm{ml}$ of the drug to be injected to one nail quadrant; $30 \mathrm{G}$ needle) with the addition of $1 \%$ lidocaine (or sodium chloride). It is recommended to repeat the treatment every 4-5 weeks for at least (!) 4-6 months. Experts recommend local anesthesia with ethyl chloride in the case of injection into the area of nail matrix, and regional anesthesia in the case of injection in the area of nail bed. Relatively common complications of these procedures include hematomas and a transient sensation of numbness in distal phalanges. Among nail area drug administration techniques, the 'fan technique' proposed by Bertrand Richert, that requires 3 injections ( $1^{\text {st }}$ in the long axis of the nail, $2^{\text {nd }}$ and $3^{\text {rd }}$ at an angle of $45^{\circ}$ and $-45^{\circ}$ in relation to the first, to the proximal shaft or hyponychium, depending on location of the most severe changes), deserves particular attention. Absence of effects after 6 treatments is an indication for discontinuation of injection treatment, while in the event of visible improvement, it is recommended to continue with a gradual extension of intervals between injections (e.g., every 6-8 weeks). The discussed form of therapy is recommended es- znokciowych). Szczególnie dramatycznie i niekorzystnie rokowniczo przebiegają postacie pęcherzowa i nadżerkowa LP w obrębie paznokci, które najczęściej dotyczą stóp i są niezwykle bolesne, a nieleczone prowadzą do trwałej utraty płytek paznokciowych (anonychia). Także idiopatyczna atrofia paznokci (idiopathic atrophy of the nails), cechująca się nagłym, bezbolesnym przebiegiem, jest obecnie traktowana jako rzadki, szczególnie ciężki wariant LP, który występuje u Azjatów i Afroamerykanów.

Diagnostyka różnicowa NLP jest trudna i opiera się na odpowiednio wcześnie i właściwie (w zależności od obrazu klinicznego zmian) wykonanej biopsji. Do jednostek chorobowych wymagających różnicowania z NLP należą: zmiany związane z procesem starzenia się paznokci, zmiany paznokci w przebiegu radioterapii, grzybica paznokci, łuszczyca, zespół Stevensa-Johnsona, zespół żółtych paznokci, układowa amyloidoza, zmiany wypryskowe oraz liszaj pasmowaty. W podręczniku onychologii Barana i Dawbera zwrócono uwagę na możliwość rozwijania się czerniaka bezbarwnikowego aparatu paznokciowego manifestującego się podobnie do NLP [3].

Leczenie NLP wciąż jest wyzwaniem dla lekarzy, a we współczesnym piśmiennictwie zwraca się uwagę na konieczność odpowiednio wczesnego włączenia intensywnej terapii (true nail emergency) [6]. W 2020 r. grupa międzynarodowych ekspertów na łamach „Journal of the American Academy of Dermatology" opublikowała pierwsze zalecenia dotyczące terapii NLP [7]. Autorzy dokonali podziału nasilenia zmian, podkreślając, że zarówno skrzydlik grzbietowy, jak i anonychia należą do najcięższych postaci choroby, niereagujących na żadną formę terapii. Na podstawie doświadczeń własnych oraz przeglądu piśmiennictwa (21 publikacji z bazy danych PubMed) opracowano praktyczny algorytm terapeutyczny, w którym wyszczególniono podział oparty na liczbie zajętych paznokci („do 3" oraz „powyżej 3”), zajęciu macierzy paznokcia i/lub łożyska paznokcia.

Autorzy rekomendują miejscowe iniekcje $\mathrm{z}$ acetonidu triamcynolonu (I linia terapeutyczna; stężenie 2,5-5,0$10,0 \mathrm{mg} / \mathrm{ml}$ w zależności od nasilenia zmian; 0,1 ml leku do ostrzyknięcia jednego kwadrantu paznokcia; igła 30G) z dodatkiem 1\% lidokainy (bądź chlorku sodu). Rekomendowane jest powtarzanie zabiegów co 4-5 tygodni przez co najmniej (!) 4-6 miesięcy. Eksperci zalecają miejscowe znieczulenie chlorkiem etylu w przypadku iniekcji w okolice macierzy paznokcia, natomiast znieczulenie przewodowe w razie podania leku w okolicę łożyska paznokcia. Do stosunkowo częstych powikłań tych procedur należą krwiaki oraz przemijające uczucie drętwienia dystalnych paliczków. Spośród technik podawania leku w okolice aparatu paznokciowego na szczególną uwagę zasługuje technika wachlarza zaproponowana przez Bertranda Richerta, wymagająca przeprowadzenia 3 iniekcji (I w osi długiej paznokcia, II i III pod kątem $45^{\circ}$ i $-45^{\circ}$ 
pecially in cases of mild-to-moderate NLP with nail matrix involvement. In the case of changes involving more than 3 nails (regardless of their severity!), and the combined involvement of the nail matrix and bed (up to 3 nails), or in cases of severe NLP (up to 3 nails), experts recommend adding triamcinolone acetonide in intramuscular injections (the first line therapy, dose of $0.5-1.0 \mathrm{mg} / \mathrm{kg}$ ) administered once a month for 3-6 months. In the authors' opinion, adverse effects of this form of systemic steroid therapy are significantly lower than in the case of daily oral steroid therapy, which is not recommended in isolated NLP. If a patient does not consent to steroid therapy, oral retinoids are recommended: acitretin $0.2-$ $0.3 \mathrm{mg} / \mathrm{kg} /$ day or alitretinoin $30 \mathrm{mg} /$ day (as the second line therapy). The recommendations emphasize the superiority of alitretinoin, which is better tolerated by patients, shows greater anti-inflammatory activity, and regulates differentiation and proliferation of keratinocytes better.

Authors of the article allow the use of azathioprine (dose: $100 \mathrm{mg} /$ day), cyclosporin A (dose: 3-5 mg/ $\mathrm{kg}$ /day) and mycophenolate mofetil (dose: $2 \mathrm{~g} /$ day) in NLP therapy, especially in cases of no improvement after the steroid treatment (third line therapy).

The necessity to start NLP therapy as early as possible (the "wait and see" attitude is contraindicated in this disease) is worth special attention because of the difficult-to-predict course of this form of LP. Therefore, it is also necessary to monitor the effectiveness of the current treatment carefully, and immediately change the therapeutic strategy in case of unsatisfactory effects (due to the rate of nail plate growth, the assessment should be made every 3-6 months).

The proposed recommendations are greatly consistent with the recommendations of the European Academy of Dermatology and Venereology (regarding general rules of conduct in the LP) [8]. It should be noted, however, that so far there is little information available on NLP therapy that would allow for conclusions based on principles of evidence-based medicine, which a result of absence of adequate research. This implies the need for a particularly careful, individual assessment of each identified case of NLP, prior to implementation of the procedure.

Recently, new therapeutic guidelines for the treatment of NLP during the COVID pandemic have been published, in which attempts of therapy with strong topical glucocorticosteroids used under the occlusion (which eliminates the need for regular medical visits) were deemed acceptable [9].

\section{CONFLICT OF INTEREST}

The authors declare no conflict of interest. względem I; możliwa w okolicy wału proksymalnego bądź hyponychium, w zależności od lokalizacji najbardziej nasilonych zmian). Brak efektu po 6 zabiegach stanowi wskazanie do przerwania leczenia metodą iniekcji, natomiast w przypadku widocznej poprawy zalecana jest kontynuacja ze stopniowym wydłużaniem okresów pomiędzy iniekcjami (np. co 6-8 tygodni). Dyskutowana forma terapii wskazana jest szczególnie w przypadkach łagodnych i średnio nasilonych postaci NLP przy zajęciu macierzy paznokcia. W przypadku zmian obejmujących powyżej 3 paznokci (niezależnie od ich stopnia nasilenia!) oraz przy łącznym zajęciu przez proces zapalny macierzy i łożyska paznokcia (do 3 paznokci) bądź w sytuacjach ciężkiego NLP (do 3 paznokci) eksperci rekomendują dołączenie do terapii acetonidu triamcynolonu $\mathrm{w}$ formie iniekcji domięśniowych (I linia terapeutyczna, dawka 0,5-1,0 mg/ $\mathrm{kg}$ ) podawanych $1 \mathrm{raz} \mathrm{w}$ miesiącu przez 3-6 miesięcy. Według autorów opracowania objawy niepożądane tej formy glikokortykosteroidoterapii ogólnej są znacząco mniejsze niż codziennej glikokortykosteroidoterapii doustnej, która w izolowanym NLP nie jest zalecana. W przypadku braku zgody pacjenta na glikokortykosteroidoterapię zaleca się retinoidy doustne: acytretynę 0,2-0,3 mg/kg/dobę lub alitretynoinę $30 \mathrm{mg} /$ dobę (jako II linia terapeutyczna). W rekomendacjach podkreślono wyższość alitretynoiny, która jest lepiej tolerowana przez pacjentów, cechuje się większą aktywnością przeciwzapalną, a także lepiej reguluje różnicowanie i proliferację keratynocytów.

Autorzy artykułu dopuszczają użycie w terapii NLP azatiopryny (dawka: $100 \mathrm{mg} /$ dobę), cyklosporyny A (dawka: 3-5 mg/kg/dobę) oraz mykofenolanu mofetylu (dawka: $2 \mathrm{~g} /$ dobę), zwłaszcza w przypadku braku poprawy po glikokortykosteroidach (III linia terapeutyczna).

Eksperci podkreślają znaczenie jak najwcześniejszego rozpoczynania terapii NLP (postawa wait and see jest w tej chorobie przeciwwskazana) ze względu na trudny do przewidzenia przebieg tej postaci LP. W związku z tym konieczne jest też uważne monitorowanie skuteczności bieżącego leczenia i natychmiastowa zmiana strategii w przypadku niewystarczającego efektu (ze względu na szybkość wzrostu płytki paznokciowej ocena powinna następować co 3-6 miesięcy).

Proponowane rekomendacje w głównych punktach są zgodne z zaleceniami Europejskiej Akademii Dermatologii i Wenerologii dotyczącymi ogólnych reguł postępowania w LP [8]. Należy jednak zaznaczyć, że do tej pory $\mathrm{z}$ powodu braku odpowiednich badań mamy niewiele informacji dotyczących terapii NLP pozwalających na wnioskowanie zgodne z regułami medycyny opartej na dowodach. Implikuje to konieczność szczególnie ostrożnej, indywidualnej oceny każdego rozpoznanego przypadku NLP przed wdrożeniem postępowania.

Ostatnio ukazały się kolejne wskazówki dotyczące terapii NLP w trakcie pandemii COVID, w których za 
dopuszczalne uznano między innymi próby leczenia za pomocą silnych miejscowych glikokortykosteroidów stosowanych pod okluzją (co eliminuje konieczność cyklicznych wizyt lekarskich) [9].

\section{KONFLIKT INTERESÓW}

Autorzy nie zgłaszają konfliktu interesów.

\section{References}

\section{Piśmiennictwo}

1. Tziotzios C., Lee J.Y.W., Brier T., Saito R., Hsu C.K., Bhargava K., et al.: Lichen planus and lichenoid dermatoses: clinical overview and molecular basis. J Am Acad Dermatol 2018, 79, 789-804.

2. Bolognia J.L., Schaffer J.V., Cerroni L.: Dermatology. Elsevier, Oxford, 2017.

3. Baran R., de Berker D.A.R., Holzberg M., Piraccini B.M., Richert B., Thomas L.: Baran and Dawber's Diseases of the Nails and their Management. Wiley-Blackwell, Hoboken, 2018.

4. Jaworek A., Jaworek M., Zalewski A., Mazgaj M., Kurzawa M., Wojas-Pelc A.: A review of practical related to the diseases of the nail unit for doctors (including nondermatologists). Pediatr Med Rodz 2020, 16, 62-69.

5. Lipner S.R.: Nail lichen planus: a true nail emergency. J Am Acad Dermatol 2019, 80, e177-e178.

6. Husein-El A.H., Gieler U., Steinhoff M.: Lichen planus: a comprehensive evidence-based analysis of medical treatment. J Eur Acad Dermatol Venereol 2019, 33, 1847-1862.

7. Iorizzo M., Tosti A., Starace M., Baran R., Daniel C.R. $3^{\text {rd }}$, Di Chiacchio N., et al.: Isolated nail lichen planus: an expert consensus on treatment of the classical form. J Am Acad Dermatol 2020, 83, 1717-1723.

8. Ioannides D., Vakirlis E., Kemeny L., Marinovic B., Massone C., Murphy R., et al.: European S1 guidelines on the management of lichen planus: a cooperation of the European Dermatology Forum with the European Academy of Dermatology and Venereology. J Eur Acad Dermatol Venereol 2020, 34, 1403-1414.

9. Ricardo J.W., Lipner S.R.: Recommendations for treatment of nail lichen planus during the COVID-19 pandemic. Dermatol Ther 2020, 33, e13551.

Received: 8.12 .2020

Accepted: 26.12 .2020

Otrzymano: $8.12 .2020 \mathrm{r}$.

Zaakceptowano: $26.12 .2020 \mathrm{r}$.

How to cite this article

Jaworek A.K., Hałubiec P., Maciejowska-Podosek J., Wojas-Pelc A: Practical commentary on therapeutic guidelines for isolated nail lichen planus 2020. Dermatol Rev/Przegl Dermatol 2021, 108, 77-80. DOI: https://doi.org/10.5114/dr.2021.105899. 